\title{
Weed Suppression With Babassu Straw and spatial Rice Arrangement
}

\author{
Denise Lima Cavalcante Marinho (Corresponding author) \\ State University of Tocantina Region of Maranhão, Center for Exact, Natural and \\ Technological Sciences, Imperatriz, Maranhão, Brazil. E-mail: deniselcaval@gmail.com
}

\begin{abstract}
Raimundo Nonato Viana Santos
State University of Maranhão, Weed Laboratory, São Luis, Maranhão, Brazil. E-mail: rvianasantos@gmail.com
\end{abstract}

Ivaneide de Oliveira Nascimento

State University of Tocantina Region of Maranhão, Center for Exact, Natural and Technological Sciences, Imperatriz, Maranhão, Brazil. E-mail: Ivaneide_agro@yahoo.com.br

\section{Maria José Pereira Corrêa}

State University of Maranhão, Chemistry and Biology Department, São Luis, Maranhão, Brazil. E-mail: mjcorreazea@ hotmail.com.br

\section{Maria Rosângela Malheiros Silva}

State University of Maranhão, Department of Phytotechnics and Plant Health, São Luis, Maranhão, Brazil. E-mail: romalheir@gmail.com

Received: May 5, 2020

doi:10.5296/jas.v8i3.16974
Accepted: June 12, $2020 \quad$ Published: June 22, 2020

URL: https://doi.org/10.5296/jas.v8i3.16974

\begin{abstract}
Soil cover and spatial crop arrangement are practices that can suppress weeds. The study aimed to evaluate the babassu straw cover and the spatial arrangement of rice crops as weed control. The experiment was conducted in two rice arrangements spatial, the first, with a spacing of $35 \mathrm{~cm}$ and sowing density of $87 \mathrm{~kg} \mathrm{ha}^{-1}\left(\mathrm{~S}_{35} \mathrm{D}_{87}\right)$; and the second, with a spacing of
\end{abstract}


$45 \mathrm{~cm}$ and sowing density of $68 \mathrm{~kg} \mathrm{ha}^{-1}\left(\mathrm{~S}_{45} \mathrm{D}_{68}\right)$, and four amounts of babassu straw $(0.0 ; 8.5$; 12.5 and $16.5 \mathrm{t} \mathrm{ha}^{-1}$ ). Weed density, dry mass, phytosociology, and crop productivity were assessed. Babassu straw at $16.5 \mathrm{t} \mathrm{ha}^{-1}$ in the two crop arrangements reduced weed density from 66.8 to $76.2 \%$ and increased rice productivity. The most important weeds were Cyperus spp, Murdania nudiflora (L.) Brenan and Phyllanthus niruri L. Babassu straw cover and rice crop arrangement were efficient in the weeds suppression.

Keywords: Oryza sativa L., mulch, infesting community

\section{Introduction}

Rice (Oryza sativa L.) is a crop that has socio-economic importance in Brazil due to its nutritional balance and growth potential in all regions in the country. In the 2017/2018 harvest, Brazilian crop was 12,064.2 thousand tons and the major producing regions were South (9,743.1), followed by North (1,065.7 thousand tons), Mid-Western (676.5 thousand tons) and Northeast (525.9 thousand tons), in which Maranhão heads the list of more producing states, with a production of 320.9 thousand tons (CONAB, 2019).

In Maranhão, rice is a cereal widely cultivated by family farmers in the upland system in which weeds are considered one of the major biological restrictions. Weeds compete with the crop for limited resources, such as nutrients, moisture, light, space, among others (Chauhan et al., 2014).

Weeds, when not controlled in upland rice grown, could cause yield losses of up to $83.5 \%$ (Silva et al., 2015). These points to the negative impact of these species on the crop, and the importance of implementing management practices that keeps the populations at low levels of economic damages.

Chemical control is one of the most widely used weed management methods in rice cultivation. However, Chauhan et al. (2014), highlighted the unsustainability of this control over the long-term due to environmental contamination and induction of resistance. They further emphasize the need to develop sustainable strategies in different rice cultivation systems.

Among the sustainable strategies to cultivate rice, several studies suggest the spatial arrangement of the crop, by changing the seeding spacing and density between the lines (Chauhan \& Johnson, 2011; Kaur \& Singh, 2014; Ahmed et al., 2014) and the use of mulch (Chauhan \& Abugho, 2013; Yadav et al., 2018; Ranaivoson et al., 2018).

Chauhan \& Johnson (2011) found that reducing rice spacing from 30 to $15 \mathrm{~cm}$ decreased weed biomass and increased yield. Though, Ahmed et al. (2014) noted this reduction with the rice densification from 20 to $100 \mathrm{~kg} \mathrm{ha}^{-1}$, and Kaur \& Singh (2014) with a sowing density of $50 \mathrm{~kg} \mathrm{ha}^{-1}$ compared to 20,30 and $\mathrm{kg} \mathrm{ha}^{-1}$.

The use of mulch in the rice crop may also be an effective strategy for the management of weeds by inhibiting the light penetration to the soil surface (Abouziena \& Haggag, 2016) and the possible chemical effects of the released substances (Oliveira Jr et al., 2014).

Yadav et al. (2018) found that coverage of $2.5 \mathrm{t} \mathrm{ha}^{-1}$ of rice straw, gliricidia and cowpea beans 


\section{I Macrothink}

suppressed the weeds in rice crops. However, Ranaivoson et al. (2018) observed efficiency with more than $10 \mathrm{t} \mathrm{ha}^{-1}$ of stylosanthes residues and corn with lab-lab. These results imply that in addition to the amount of crop residues, the quality is also significant for the weeds suppression.

In the north-central region of the State of Maranhão, a common practice among family farmers is the use of babassu palm leaves (Orbignya phalerata Mart.) as mulch to reduce weed infestation in their annual crops. Leaves are spread in the crops, but without defining the amount of crop and arrangement that effectively suppresses weeds. Thus, the research supports the hypothesis that the soil cover with babassu straw associated with an adequate spatial arrangement of the rice crop decreases weeds populations and their negative effects on crop productivity.

Based on the above considerations, studies on the crop arrangement and the amount of babassu straw that is adequate to reduce weed competition in the rice crop are necessary for the establishment of sustainable management strategies for these species. Therefore, this study aimed to evaluate the coverage of babassu straw and the spatial arrangement of rice culture as weed control.

\section{Material and Methods}

The experiment was carried out at School Farm in the Universidade Estadual do Maranhão in the municipality of São Bento, located in Baixada Maranhense, Maranhão state (MA), Brazil at $02^{\circ} 41^{\prime} 45$ "S and 44⒋'17" W, from March to July 2015. According to Köppen, the climate of the region is classified as Aw, that is, hot and humid tropical weather with two well-defined periods: rainy (January to June) and dry (July to December). The average monthly rainfall and temperature data obtained during the conduction of the experiment are shown in Figure 1.

To determine the physical-chemical characteristics of the soil, sampling was made in the experimental area at a depth of $0-0.20 \mathrm{~m}$. The soil was classified as Loamy sand texture, with the following results: fine sand $=79 \%$; clay $=16 \%$, silt $=4 \%$ and coarse sand $=1 \%$; organic matter $=11 \mathrm{~g} \mathrm{dm}^{-3} ; \mathrm{pH}(\mathrm{CaCl} 2)=4.1 ; \mathrm{P}=5 \mathrm{mg} \mathrm{dm}^{-3} ; \mathrm{K}=3.5 \mathrm{mmolc} \mathrm{dm}^{-3} ; \mathrm{Ca}=8 \mathrm{mmolc}$ $\mathrm{dm}^{-3} ; \mathrm{Mg}=5$ mmolc dm ${ }^{-3} ; \mathrm{H}+\mathrm{Al}=32$ mmolc dm$^{-3}$. 


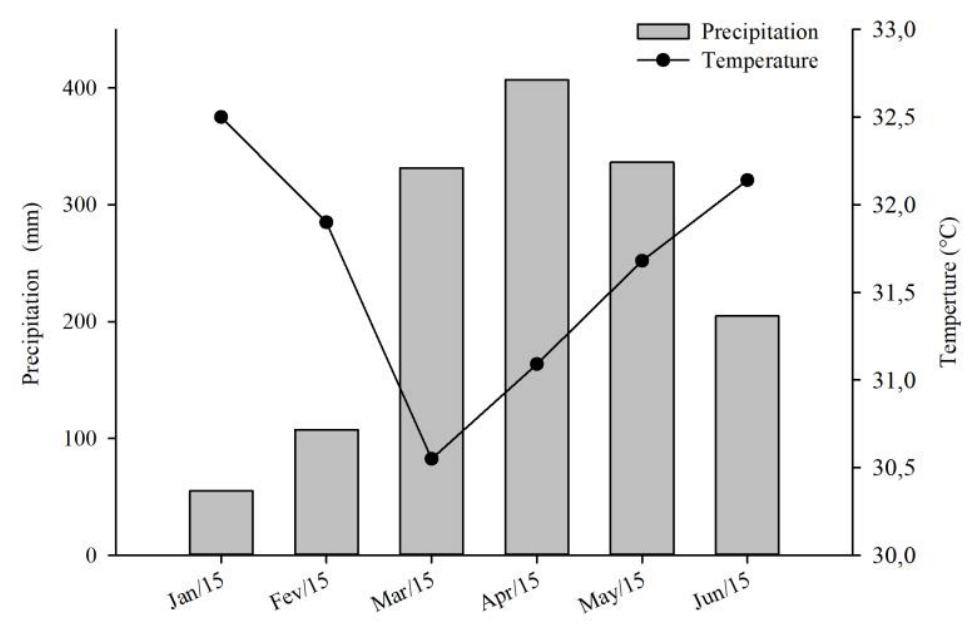

Figure 1. Precipitation and mean temperature during the crop cycle in São Bento - MA, 2015. Source: INMET, 2015

The experimental design was laid out in randomized blocks with four repetitions. The treatments were arranged in a $2 \times 4$ factorial scheme: crop spatial arrangement, $0.35 \mathrm{~m}$ spacing with sowing density of $87 \mathrm{~kg} \mathrm{ha}^{-1} \quad\left(\mathrm{~S}_{35} \mathrm{D}_{87}\right)$ and $0.45 \mathrm{~m}$ spacing, with density $68 \mathrm{~kg}$ $\mathrm{ha}^{-1}\left(\mathrm{~S}_{45} \mathrm{D}_{68}\right)$; and the amount of babassu straw on a wet basis $\left(0.0,8.5,12.5\right.$ and $16.5 \mathrm{tha}^{-1}$ of a straw). The control corresponded to the treatment $0.0 \mathrm{t}$ ha- 1 of straw, that is, the absence of straw and weed control. The treatments were not weeded during the growth cycle, except at ten days after emergence (DAE), when crushed babassu straw was placed. The plots consisted of six lines of $5.0 \mathrm{~m}$ with usable area formed by the two central lines, disregarding $0.50 \mathrm{~m}$ from each end.

The soil preparation was done using two harrowings, one for lime incorporation and another, before crop sowing. Planting fertilization contained $200 \mathrm{~kg} \mathrm{ha}^{-1}$ of formulation 5-30-15 and in coverage of $91 \mathrm{~kg} \mathrm{ha}^{-1}$ of $\mathrm{N}$ in the urea form.

Rice sowing was carried out with hand seed planters, on March 13, 2015, using the upland rice cultivar BRS Esmeralda, which has high productivity, intermediate plant architecture, height between 95 and $108 \mathrm{~cm}$, good early vigor, and rapid canopy closure, resulting in good competitiveness with weeds (Castro et al., 2014).

Babassu palm leaves were collected from adult plants near the place where the experiment was conducted. Then, the leaves were crushed in a Trapp forage shredder machine, model TRF 400, weighed, and manually distributed between the rows of rice according to each treatment.

The weed survey was carried out at 20,30, 40, 50, 60, 70, and 110 DAE of the cultivars by the random launch of a $0.50 \times 0.30 \mathrm{~m}$ leaked metal frame four times between crop lines in each plot, totaling an area of $0.6 \mathrm{~m}^{2}$. The plants were counted, identified, and bagged for drying in the forced-ventilation oven at $65^{\circ} \mathrm{C}$ and then, weighed on a precision scale. 
The results of weed density and dry mass were expressed as a number of plants $\mathrm{m}^{-2}$ and $\mathrm{g} \mathrm{m}^{-2}$, respectively. These data for each species were used to determine phytosociological indices, relative density (R.De), relative frequency (R.Fr), relative dominance (R.Do), and importance value index (IVI), according to Pitelli (2000).

The harvest was carried out manually at 110 DAE when more than $95 \%$ of the panicles were ripe and the productivity obtained by the weight of grains harvested with the humidity correction to $13 \%$.

The results were subjected to analysis of variance and a comparative test of means by the Scott \& Knott test at 5\% probability, using the AgroEstat software (Barbosa \& Maldonado Júnior, 2015). Regression analysis was used to analyze the effect of the amounts of babassu straw in the evaluated periods (SigmaPlot 11, Systat Software Inc.).

\section{Results and Discussion}

In this work, 45 weed species distributed in 19 botanical families were identified, with 11 species in the Cyperaceae family, followed by Fabaceae and Poaceae with seven and five species, respectively.

Studies conducted by Silva et al. (2015), Silva et al. (2017) and Costa et al. (2018) in rice crop showed the diversity of weed species is elevated in this crop, also that the Poaceae and Cyperaceae families are the most relevant. Chauhan et al. (2014), stated that the importance of the species of these families in rice crops derived from the fascicular root systems, making them more competitive, such as rice for water and nutrients.

It was possible to notice that there was a significant effect of the interaction between the crop spatial arrangement, the amounts of babassu straw, and the evaluation periods for weed density. The unfolding of arrangement $\left(\mathrm{S}_{35} \mathrm{D}_{87}\right.$ and $\mathrm{S}_{\left.45 \mathrm{D}_{68}\right)}$ within the amounts of straw showed that the highest and lowest weed densities occurred in 0.0 and $16.5 \mathrm{t} \mathrm{ha}^{-1}$ of babassu straw, respectively (Table 1).

The higher weeds density in the absence of straw was probably due to the soil exposure to light that promoted the emergence of these species. Yadav et al. (2018), in their research, also found a high weed density in rice in the absence of mulch (213.7 to 320.3 plants $\mathrm{m}^{-2}$ ) about cover treatments.

Moreover, the low weed densities in the straw cover might be related to the lesser light passage for the germination of these species. Chauhan \& Gill (2014) affirm that large amounts of residues on the soil can reduce and delay the emergence of weeds by inhibition of light penetration and decreasing the thermal amplitude.

The amounts of babassu straw within the arrangements differed significantly for weed density only by $0.0 \mathrm{t} \mathrm{ha}^{-1}$ of babassu straw with the lowest value in the arrangement $\mathrm{S}_{35} \mathrm{D} 87$ (Table 1).

The absence of mulch revealed that the crop arrangement also influenced the emergence of the weeds, but with less suppression on these species because in the presence of babassu straw, weed densities were similar between the arrangements. 


\section{Macrothink

Additionally, it can be seen that the spacing reduction improves the competitiveness of crops by the rapid canopy development that allows less light to the soil (Chauhan \& Gill, 2014) and provides less space for weed emergence (Kaur \& Singh, 2014). However, in this experiment, the use of mulch showed higher interference in weed density.

Table 1. Effect of the interaction of the spatial arrangement of rice and the amount of babassu straw on weed density (plants $\mathrm{m}^{-2}$ ). São Bento - MA, 2015

\begin{tabular}{lrrrr}
\hline \multirow{2}{*}{ Spatial arrangement } & \multicolumn{5}{c}{ Amount of babassu straw $\left(\mathrm{t} \mathrm{ha}^{-1}\right)$} \\
\cline { 2 - 5 } & 0.0 & 8.5 & 12.5 & 16.5 \\
\hline $\mathrm{S}_{35} \mathrm{D}_{87}$ & $117.95 \mathrm{bA}$ & $60.50 \mathrm{aB}$ & $50.77 \mathrm{aB}$ & $39.20 \mathrm{aC}$ \\
$\mathrm{S}_{45} \mathrm{D}_{68}$ & $149.49 \mathrm{aA}$ & $65.78 \mathrm{aB}$ & $47.58 \mathrm{aC}$ & $35.63 \mathrm{aD}$ \\
\hline $\mathrm{CV} \%$ & \multicolumn{4}{c}{27,87} \\
\hline
\end{tabular}

*Means followed by the same lowercase letter in the columns and uppercase in the row do not differ from each other by the Scott \& Knott test $(\mathrm{p}<0.05)$.

Deployment of the amounts of babassu straw in the periods for weed density was adjusted to quadratic equations (Figure 2). The highest weed density was found in $0.0 \mathrm{t} \mathrm{ha}^{-1}$ of straw in all periods compared to cover treatments. These were increased from 20 to $50 \mathrm{DAE}$, however, with reductions from 60 DAE until harvest.

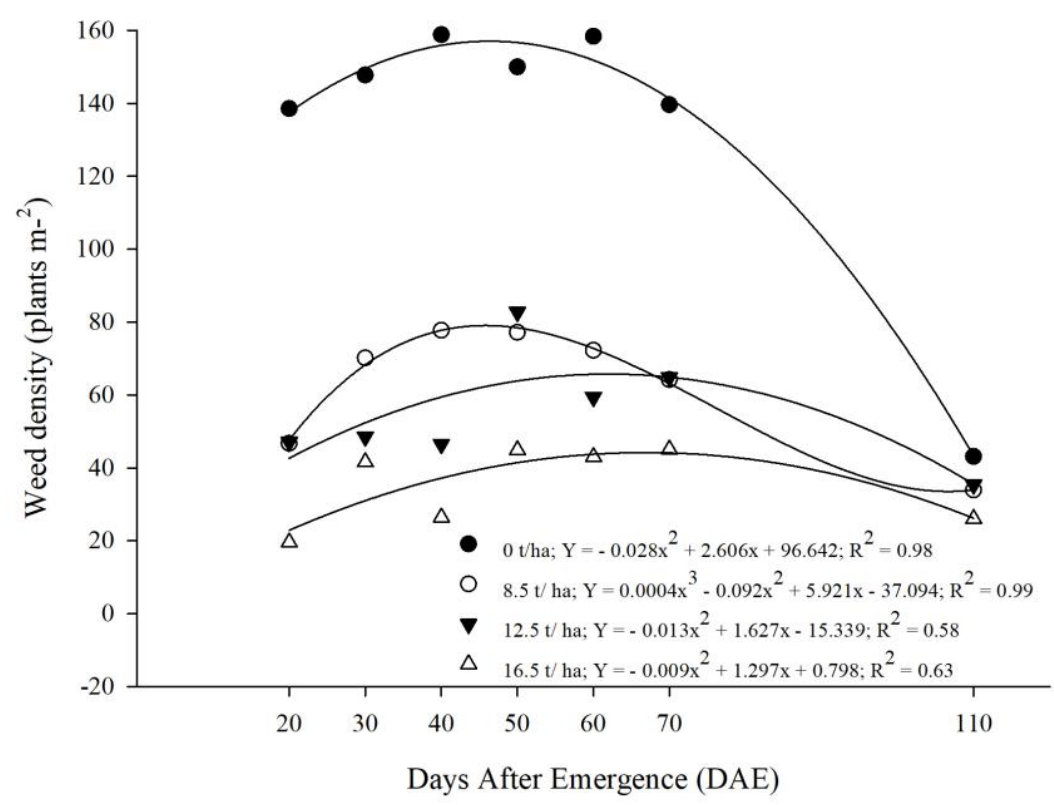

Figure 2. Weed density (plants $\mathrm{m}^{-1}$ ) in the control and treatments with babassu straw during 
the rice crops cycle. São Bento - MA, 2015

The increase in weed density by $0.0 \mathrm{t} \mathrm{ha}^{-1}$ in the early evaluations appears that it was due to the greater exposure to light, followed by decreases after 60 DAE by crop shading. Yadav et al. (2018) also related the decreases in weed density with crop growth and soil shading.

Babassu straw treatments suppressed weeds before 50 DAE. It corresponds to the critical period of upland rice cultivation, which suggests lower production losses. Chauhan et al. (2014) and Ranaivoson et al. (2018) reported that weeds that germinate after the critical period are less harmful to crop productivity.

Regarding weed dry mass, it was not noticed any significant interaction between the crop spatial arrangement, the amounts of babassu straw, and the evaluated periods. However, to observe this weed behavior, the deployment of the interactions of amounts of babassu straw was performed.

The lowest dry mass accumulation occurred in $16,5 \mathrm{t} \mathrm{ha}^{-1}$ of straw, whereas the highest values were obtained in $0.0 \mathrm{t} \mathrm{ha}^{-1}$ (Table 2).

Light reduction, due to the higher soil coverage, besides preventing the emergence of many weeds, probably also interfered in the dry mass accumulation of species that have passed through the physical barrier of babassu straw.

Table 2. Effect of the amount of babassu straw on rice culture arrangements on weed dry mass $\left(\mathrm{g} \mathrm{m}^{-2}\right)$. São Bento - MA, 2015

\begin{tabular}{lrrrr}
\hline \multirow{2}{*}{ Spatial arrangement } & \multicolumn{4}{c}{ Amount of babassu straw $\left(\mathrm{t} \mathrm{ha}^{-1}\right)$} \\
\cline { 2 - 5 } & 0.0 & 8.5 & 12.5 & 16.5 \\
\hline $\mathrm{S}_{35} \mathrm{D}_{87}$ & $40.26 \mathrm{~A}$ & $26.24 \mathrm{~B}$ & $20.94 \mathrm{C}$ & $15.49 \mathrm{D}$ \\
$\mathrm{S}_{45} \mathrm{D}_{68}$ & $41.91 \mathrm{~A}$ & $26.30 \mathrm{~B}$ & $19.87 \mathrm{C}$ & $15.06 \mathrm{D}$ \\
\hline $\mathrm{CV} \%$ & & \multicolumn{4}{c}{21.15} \\
\end{tabular}

*Means followed by the same uppercase letter on the line do not differ from each other by the Scott \& Knott test $(\mathrm{p}<0.05)$.

The weed dry mass in the $\mathrm{S}_{35} \mathrm{D}_{87}$ arrangement was reduced at $35 \%$ for $8.5 \mathrm{t} \mathrm{ha}^{-1}$ of straw, $48 \%$ for $12.5 \mathrm{t} \mathrm{ha}^{-1}$, and $61.53 \%$ for $16.5 \mathrm{t} \mathrm{ha}^{-1}$ compared to $0.0 \mathrm{t} \mathrm{ha}^{-1}$ of this arrangement. In $\mathrm{S}_{45} \mathrm{D}_{68}$, the reduction at $8.5,12.5$ and $16.5 \mathrm{t} \mathrm{ha}^{-1}$ of straw were $32.27,52.60$ and $64.08 \%$, respectively, compared to $0.0 \mathrm{t} \mathrm{ha}^{-1}$ (Table 2).

It is important to emphasize that despite the efficiency of the high amount of babassu straw on the weed dry mass, the lower amount of straw also affected the growth of these species.

Ranaivoson et al. (2018) also showed reductions in rice of 59 and $48 \%$ in the weed dry mass with $10 \mathrm{t} \mathrm{ha}^{-1}$ of styling plant residues and corn with the lab-lab. Yadav et al. (2018) observed 


\section{Mll Macrothink}

the major losses with $2.5 \mathrm{t} \mathrm{ha}^{-1}$ of rice straw cover (65.69\%), gliricidia (73.81\%), and cowpea residues $(68.08 \%)$.

These results suggest that the type of residue influences the amount of coverage required to suppress weeds and also points to the relevance of performing studies with different residues in rice crops.

Although there was no significant interaction between the amounts of babassu straw and the periods of dry weed mass, the deployment was carried out. As a result, the quadratic equations were obtained (Figure 3), where the increasing dry mass accumulations from 20 to $110 \mathrm{DAE}$ with higher values in $0.0 \mathrm{t} \mathrm{ha}^{-1}$ of straw were observed.

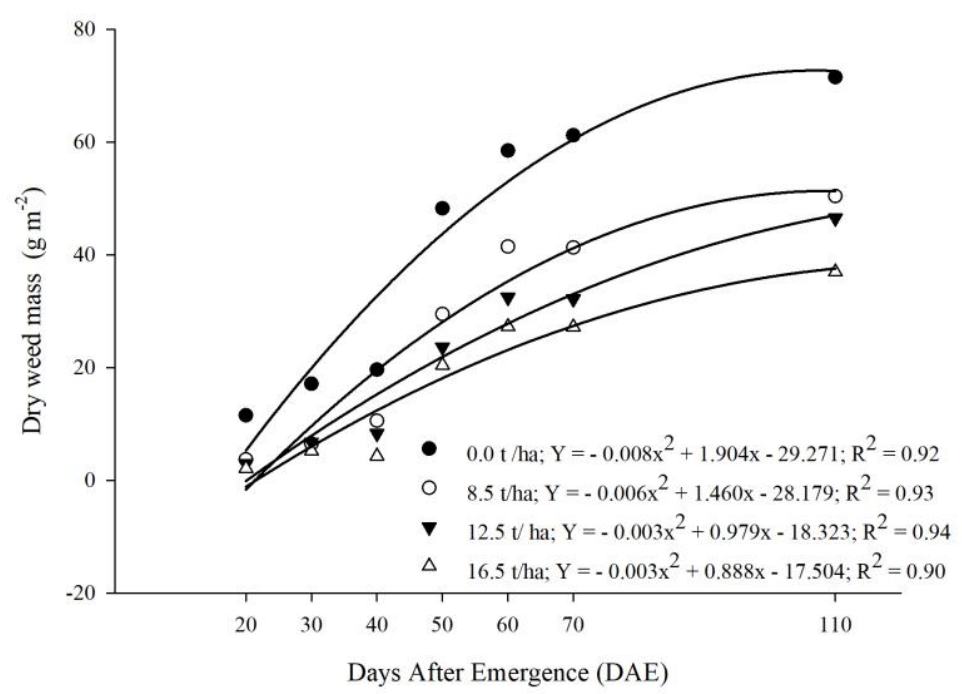

Figure 3. Dry weed mass $\left(\mathrm{g}^{\mathrm{m}-2}\right)$ in the control and babassu straw treatments during the rice culture cycle. São Bento - MA, 2015

As there are few studies on babassu straw allelopathy of weeds, it is believed that the smallest accumulations of dry weed mass by straw additions, possibly were due to the shading caused by mulch. However, Oliveira Jr et al. (2014), cited that due to the multiple effects of mulch on the soil, allelopathy should not be disregarded in suppressing weeds.

The smallest accumulations of dry weed mass by straw additions possibly were due to the shading caused by mulch, as studies of babassu straw allelopathy on weeds are scarce. However, Oliveira Jr et al. (2014), cited that due to the multiple effects of mulch on the soil, allelopathy should not be disregarded in suppressing weeds.

Besides, Chauhan \& Abugho (2013) assigned to the increase in rice residues, from 3 to $6 \mathrm{t}$ $\mathrm{ha}^{-1}$, the reduction and delay in the appearance of many weeds on the rice cultivar that could result in a reduced crop yield loss and fewer weeds seeds for the next planting.

The weeds with the highest Importance Value Index (IVI) at $0.0 \mathrm{t} \mathrm{ha}^{-1}$ of straw in the $\mathrm{S}_{35} \mathrm{D}_{87}$ arrangement were Cyperus spp. (represented by Cyperus brevifolius, Cyperus diffusus, Cyperus distans, Cyperus eragrostis, Cyperus esculentus, Cyperus iria and Cyperus 
sphacelatus). At $20 \mathrm{DAE}$, these species were inhibited by all treatments with straw, and at 60 DAE only by 12.5 and $16.5 \mathrm{tha}^{-1}$ of straw compared to $0.0 \mathrm{t} \mathrm{ha}^{-1}$ of straw (Table 3 ).

Species of the genus Cyperus are among the most harmful weeds to cultivate rice (Silva et al., 2015; Silva et al., 2017; Costa et al., 2018) and babassu straw. It may reduce the IVI of these species at the beginning of crop growth, probably through the shading. Chauhan \& Abugho (2013) also observed a low emergence of weeds due to light reduction by covering residues.

Although ciperaceae in other evaluations increased their infestation, possible due to the progressive straw decomposition that reduced the soil cover, the initial infestation reduction of these species allowed the crop to grow adequately. Mahajan et al. (2014) stated that most weeds in rice cultivar are of the $\mathrm{C} 4$ cycle, which has high adaptability, rapid growth, and therefore, dominates the crop and reduces its growth potential.

Another species of relevance in the $\mathrm{S}_{35} \mathrm{D}_{87}$ arrangement in all treatments was $M$. nudiflora, whose greatest IVI's were noticed at $16.5 \mathrm{t} \mathrm{ha}^{-1}$ of straw (Table 3). This species belonging to the Commelinaceae family has been reported as an important weed in soybean crops under no-tillage due to its competitiveness with the crop, difficulty in control, and rapid infestation (Luz et al., 2014).

Table 3. Importance value index - IVI (\%) of the main weeds in the rice crop in the $\mathrm{S}_{35} \mathrm{D}_{87}$ arrangement as a function of the amounts of babassu straw during the crop cycle. São Bento MA, 2015

\begin{tabular}{|c|c|c|c|c|c|c|c|}
\hline \multirow{2}{*}{ Species } & 20 & 30 & 40 & 50 & 60 & 70 & 110 \\
\hline & \multicolumn{7}{|c|}{ Days After Emergency (DAE) } \\
\hline \multicolumn{8}{|c|}{$0.0 \mathrm{t} \mathrm{ha}^{-1}$ of babassu straw } \\
\hline Cyperus spp & 106.80 & 74.35 & 87.82 & 79.92 & 82.66 & 49.51 & 16.50 \\
\hline Murdania nudiflora & 51.66 & 68.40 & 57.42 & 46.15 & 48.32 & 54.82 & 20.99 \\
\hline Phyllanthus niruri & 29.02 & 24.76 & 16.74 & 25.48 & 28.38 & 17.50 & 0.00 \\
\hline \multicolumn{8}{|c|}{$8.5 \mathrm{t} \mathrm{ha}^{-1}$ of babassu straw } \\
\hline Cyperus spp & 84.94 & 75.13 & 75.25 & 73.70 & 75.75 & 41.95 & 26.79 \\
\hline Murdania nudiflora & 55.37 & 50.04 & 51.59 & 58.65 & 53.62 & 71.54 & 66.08 \\
\hline Phyllanthus niruri & 33.98 & 33.01 & 26.86 & 51.61 & 32.10 & 18.93 & 1.40 \\
\hline \multicolumn{8}{|c|}{$12.5 \mathrm{t} \mathrm{ha}^{-1}$ of babassu straw } \\
\hline Cyperus spp & 76.96 & 71.71 & 96.21 & 81.58 & 59.45 & 56.54 & 12.98 \\
\hline Murdania nudiflora & 64.89 & 65.79 & 58.11 & 54.13 & 66.40 & 59.72 & 59.93 \\
\hline Phyllanthus niruri & 54.89 & 42.24 & 37.10 & 49.67 & 39.51 & 21.59 & 4.68 \\
\hline \multicolumn{8}{|c|}{$16.5 \mathrm{t} \mathrm{ha}^{-1}$ of babassu straw } \\
\hline Cyperus spp & 84.60 & 81.68 & 82.91 & 77.63 & 45.35 & 51.18 & 23.13 \\
\hline Murdania nudiflora & 55.64 & 75.62 & 82.37 & 76.82 & 73.28 & 82.68 & 65.00 \\
\hline Phyllanthus niruri & 67.66 & 43.15 & 57.00 & 66.59 & 43.26 & 31.57 & 4.50 \\
\hline
\end{tabular}


At $0.0 \mathrm{t} \mathrm{ha}^{-1}$ of straw in the $\mathrm{S}_{45} \mathrm{D}_{68}$ arrangement, Cyperus spp were also the dominant species and presented the highest IVI values compared to treatments with straw in this arrangement and with $0.0 \mathrm{t} \mathrm{ha}^{-1}$ of the $\mathrm{S}_{35} \mathrm{D}_{87}$ (Table 4 and 3).

The high ciperaceae IVI in the $\mathrm{S}_{45} \mathrm{D}_{68}$ arrangement was correlated with the greater space availability and the lower rice plant density plants that without straw cover allowed the infestation of these species.

Silva et al. (2015) evidenced that the higher light incidence on the soil in the initial weed periods coexistence with rice cultivation favored the cyperaceae, which are more efficient in greater luminosity due to their $\mathrm{C} 4$ carbon fixation cycle.

Babassu straw treatments in the $\mathrm{S}_{45} \mathrm{D}_{68}$ arrangement decreased the importance of Cyperus spp in all evaluations compared to $0.0 \mathrm{t} \mathrm{ha}^{-1}$ of straw in this arrangement (Table 4). It was observed that the interference of babassu straw on the Cyperaceae was more evident in this arrangement, possibly due to the lower shading of the crop resulting from the low density.

Furthermore, the species $M$. nudiflora was also relevant in the $\mathrm{S}_{45} \mathrm{D}_{68}$ arrangement with higher IVI in the treatments with straw compared to $0.0 \mathrm{t} \mathrm{ha}^{-1}$ (Table 4). The moisture retention by the straw herewith the minor shade of the crop presumably stimulated the development of this species.

Luz et al. (2014) mentioned that despite the higher germination of $M$. nudiflora in the presence of light, it likewise germinated in its absence and that its high development was due to the humidity maintained in the experiment. They also added the ability of this species to break the cover of vegetable residues.

In addition to Cyperus spp followed by $M$. nudiflora, they also stood out in the P. niruri crop arrangements, especially in the presence of babassu straw (Tables 3 and 4). This implies that changes in soil moisture, light, and temperature by mulch favored the germination and development of $P$. niruri. This species was also reported by Silva et al. (2015) among those of greater relative importance in upland rice cultivation in the humid tropic.

Table 4. Importance value index-IVI (\%) of the main weeds in the rice crop in the $\mathrm{S}_{45} \mathrm{D}_{68}$ arrangement as a function of the amounts of babassu straw during the crop cycle. São Bento MA, 2015

\begin{tabular}{lrrrrrrr}
\hline \multirow{2}{*}{ Species } & 20 & 30 & 40 & 50 & 60 & 70 & 110 \\
\cline { 2 - 7 } & \multicolumn{7}{c}{ Days After Emergency (DAE) } \\
\hline Cyperus spp & 123.66 & 108.88 & 118.79 & 106.38 & 95.95 & 75.62 & 23.37 \\
Murdania nudiflora & 34.51 & 50.65 & 34.72 & 34.08 & 25.97 & 31.21 & 16.92 \\
Phyllanthus niruri & 27.61 & 24.09 & 19.61 & 31.30 & 18.47 & 12.01 & 0.00 \\
\hline \multicolumn{7}{c}{$8.5 \mathrm{t} \mathrm{ha}^{-1}$ of babassu straw } \\
\hline Cyperus spp & 84.47 & 83.75 & 84.38 & 79.08 & 65.49 & 57.14 & 11.48 \\
Murdania nudiflora & 66.69 & 62.20 & 64.12 & 62.60 & 48.67 & 43.99 & 44.50 \\
Phyllanthus niruri & 48.21 & 40.01 & 35.07 & 41.22 & 32.34 & 26.84 & 0.00 \\
\hline & $12.5 \mathrm{t} \mathrm{ha}^{-1}$ of babassu straw \\
\hline Cyperus spp & 61.58 & 95.80 & 79.98 & 86.82 & 69.71 & 61.50 & 17.31 \\
Murdania nudiflora & 54.50 & 62.20 & 67.86 & 72.30 & 47.25 & 61.08 & 16.41
\end{tabular}




\begin{tabular}{|c|c|c|c|c|c|c|c|}
\hline Phyllanthus niruri & 51.14 & 49.43 & 33.67 & 34.90 & 18.47 & 15.28 & 1.67 \\
\hline \multicolumn{8}{|c|}{$16.5 \mathrm{t} \mathrm{ha}^{-1}$ of babassu straw } \\
\hline Сурегus spp & 68.86 & 84.35 & 83.85 & 70.20 & 58.76 & 59.51 & 19.62 \\
\hline Murdania nudiflora & 55.48 & 58.40 & 52.53 & 75.67 & 75.48 & 74.82 & 47.30 \\
\hline Phyllanthus niruri & 53.34 & 24.76 & 24.17 & 52.61 & 32.26 & 17.50 & 0.00 \\
\hline
\end{tabular}

For rice productivity, there was no significant interaction between the arrangement and the amounts of babassu straw. Nevertheless, the deployment of the arrangements in the volumes of straw showed that the rice productivity differed between arrangements just at 12.5 and $16.5 \mathrm{t}$ $\mathrm{ha}^{-1}$ of straw with higher values in $\mathrm{S}_{35} \mathrm{D}_{87}$ (Table 5).

The higher amounts of straw suggest better conservation of moisture in the soil for the growth crop, which more dense, promoted more shading on the weeds. Depar et al. (2014) and Abouziena \& Haggag (2016) reported that the use of cover over the soil favored the growth of the crops by reducing losses and increasing water use.

Nawaz et al. (2017) found higher soil moisture with residues from Sesbania which resulted in higher rice yields. Yadav et al. (2018) also observed increases in rice productivity by retaining soil moisture covered with gliricidia.

The deployment of the interaction of the amounts of babassu straw within the crop arrangements resulted in higher rice yields at $16.5 \mathrm{t} \mathrm{ha}^{-1}$. The lowest yields were observed at 0.0 $\mathrm{t}$ ha ${ }^{-1}$ with losses in $\mathrm{S}_{35} \mathrm{D}_{87}$ and $\mathrm{S}_{45} \mathrm{D}_{68}$ arrangements of $66 \%$ and $67 \%$, respectively (Table 5).

The higher amount of babassu straw caused lower weed density and dry mass, which resulted in less impact on crop productivity. Results that corroborate with Rainavoson et al. (2018), whose highest rice yields occurred in high amounts of crop residues from style plant (18.5 $\mathrm{t}$ $\left.\mathrm{ha}^{-1}\right)$, and corn and lab-lab $\left(27.6 \mathrm{tha}^{-1}\right)$

The production losses of the upland rice crop increased when only the spacing management and crop density were used, which showed the relevance of babassu straw cover for weed control. Kaur \& Singh (2014) did not obtain improvement in rice productivity due to the use of different spacing and sowing density.

Table 5. Rice productivity $\left(\mathrm{t} \mathrm{ha}^{-1}\right)$ as a function of the amounts of babassu straw and the spatial arrangement of rice. São Bento - MA, 2015

\begin{tabular}{lrrrr}
\hline \multirow{2}{*}{ Spatial arrangement } & \multicolumn{4}{c}{ Amount of babassu straw $\left(\mathrm{t} \mathrm{ha}^{-1}\right)$} \\
\cline { 2 - 5 } & 0.0 & 8.5 & 12.5 & 16.5 \\
\hline $\mathrm{S}_{35} \mathrm{D}_{87}$ & $496.16 \mathrm{aA}$ & $858.26 \mathrm{aC}$ & $1145.73 \mathrm{aB}$ & $1461.59 \mathrm{aD}$ \\
$\mathrm{S}_{45} \mathrm{D}_{68}$ & $409.33 \mathrm{aD}$ & $718.09 \mathrm{aC}$ & $919.69 \mathrm{bB}$ & $1237.00 \mathrm{bA}$ \\
\hline $\mathrm{CV} \%$ & \multicolumn{4}{c}{13.97} \\
\hline
\end{tabular}

*Means followed by the same lowercase letter in the columns and uppercase in the row do not differ from each other by the Scott \& Knott test ( $\mathrm{p}<0.05)$.

\section{Conclusions}

Babassu straw mulch and rice crop arrangements are efficient alternatives for weed control and increased upland rice crop productivity, especially in high amounts of babassu straw. 


\section{Acknowledgments}

To the Fundação de Amparo à Pesquisa e ao desenvolvimento Científico e Tecnológico do Maranhão - FAPEMA for financial support to the Research Project on the Diversity and Ecology of Arthropods, Pathogens, and Spontaneous Herbs in Rice Culture in the Maranhão Baixada, and to the State University of Maranhão by experimental area.

\section{References}

Abouziena, H. F., \& Haggag, W. M. (2016). Weed control in clean agriculture: a review. Planta Daninha, 34(2), 377-392. https://doi.org/10.1590/S0100-83582016340200019

Ahmed, S., Salim, M., \& Chauhan, B. S. (2014). Effect of weed management and seed rate on crop growth under direct dry seeded rice systems in Bangladesh. PLoS ONE, 9(7), e101919. https://doi.org/10.1371/journal.pone.0101919

Barbosa, J. C., Maldonado Jr., W. (2015). Experimentação agronômica \& AgroEstat: sistema para análises estatísticas de ensaios agronômicos. Gráfica Multipress Ltda, Jaboticabal.

Castro, A. P., Morais, O. P., Breseghello, F., Lobo, V. D. S., Guimarães, C. M., Bassinello, P. Z., ... Utumi, M. M. (2014). BRS Esmeralda: cultivar de arroz de terras altas com elevada produtividade e maior tolerância à seca. Embrapa Arroz e Feijão-Comunicado Técnico (INFOTECA-E). http://www.infoteca.cnptia.embrapa.br /infoteca/handle/doc/978938

Chauhan, B. S., \& Abugho, S. B. (2013). Effect of Crop Residue on Seedling Emergence and Growth of selected weed species in a sprinkler-irrigated zero-till dry-seeded rice system. Weed Science, 61(3), 403-409. https://doi.org/10.1614/WS-D-12-00147.1

Chauhan, B. S., \& Gill, G. S. (2014). Ecologically based weed management strategies. In: Chauhan, B.S.; Mahajan, G. (ed.) Recent advances in weed management. New York- NY: Springer-Verlag, 1-11. https://doi.org/10.1007/978-1-4939-1019-9_1

Chauhan, B. S., \& Johnson, D. E. (2011). Row spacing and weed control timing affect yield of aerobic rice. Field Crops Research, 121(2), 226-231. https://doi.org/10.1016/j.fcr.2010.12.008

Chauhan, B. S., Kumar, V., \& Mahajan, G. (2014). Research needs for improving weed management in rice. Indian Journal of Weed Science, 46(1), 1-13.

CONAB. Companhia Nacional de Abastecimento. (2017). Acompanhamento da safra brasileira de grãos 2016/2017. Brasília: CONAB, 4(12).

Costa, B. P., Silva, M. R. M., de Moraes Rego, C. A. R., de Herrera, J. L., Cruz, M. S. F. V., Ristau, A. C. P., ... Machado, N. A. F. (2018). Phytosociology and Floristic Composition of the Infesting Community in Rice Crop Waterlogged. American Journal of Plant Sciences, 9(3), 353-367. https://doi.org/10.4236/ajps.2018.93028

Depar, N., Shah, J. A., \& Memon, M. Y. (2014). Effect of organic mulching on soil moisture conservation and yield of wheat (Triticum aestivum L.). Pakistan Journal of Agriculture Agricultural Engineering and Veterinary Sciences, 30(1), 54-66. https://doi.org/10.1016/j.agwat.2008.06.001

INMET, (2009). Instituto Nacional de Meteorologia. Normas climatológicas do Brasil 1961-1990. Brasília, DF. 465. http://www.inmet.gob.br 
Kaur, S., \& Singh, S. Influence of crop density on weeds, growth and yield of direct-seeded rice. Indian Journal of Weed Science, 46(4), 318-321.

Luz, F. N., Yamashita, O. M., Ferraresi, D. A., de Carvalho, M. A. C., Campos, O. R., Koga, P. S., \& Massaroto, J. A. (2014). Interferência de luz, temperatura, profundidade de semeadura e palhada na germinação e emergência de Murdannia nudiflora. Comunicata Scientiae, 5(1), 26-33.

Mahajan, G., Chauhan, B. S., Kumar, V. Integrated weed management in rice. In Chauhan, B.S.; Mahajan, G. (eds.). (2014) Recent advances in weed management. New York- NY: Springer-Verlag, 88-125. https://doi.org/10.1007/978-1-4939-1019-9_6

Nawaz, A., Farooq, M., Lal, R., Rehman, A., Hussain, T., \& Nadeem, A. (2017). Influence of sesbania brown manuring and rice residue mulch on soil health, weeds and system productivity of conservation rice-wheat systems. Land Degradation \& Development, 28(3), 1078-1090. https://doi.org/10.1002/ldr.2578

Oliveira Jr, R. S., Rios, F. A., Constantin, J., Ishii-Iwamoto, E. L., Gemelli, A., \& Martini, P. E. (2014). Grass straw mulching to suppress emergence and early growth of weeds. Planta daninha, 32(1), 11-17. https://doi.org/10.1590/S0100-83582014000100002

Pitelli, R. A. (2000). Estudos fitossociológicos em comunidades infestantes de agroecossistemas. Jornal Consherb, 1(2), 17.

Ranaivoson, L., Naudin, K., Ripoche, A., Rabeharisoa, L., \& Corbeels, M. (2018). Is mulching an efficient way to control weeds? Effects of type and amount of crop residue in rainfed rice based cropping systems in Madagascar. Field Crops Research, 217, 20-31. https://doi.org/10.1016/j.fcr.2017.11.027

Silva, M. R. M., Cantanhede, J. D., Correa, M. J. P., \& Mesquita, M. L. R. (2015). Phytosociology and interference of weeds in upland rice in Maranhão State, northeastern Brazil. African Journal of Agricultural Research, 10(34), 3412-3420. https://doi.org/10.5897/AJAR2015.9916

Silva, M. R. M., Costa, E. A., Correa, M. J. P., Rodrigues, A. A. C., \& Mesquita, M. L. R. (2017). Floristic and phytosociology of weeds in upland rice in the humid tropics. Planta Daninha, 35. https://doi.org/10.1590/s0100-83582017350100083

Yadav, G. S., Das, A., Lal, R., Babu, S., Meena, R. S., Patil, S. B., ... Datta, M. (2018). Conservation tillage and mulching effects on the adaptive capacity of direct-seeded upland rice (Oryza sativa L.) to alleviate weed and moisture stresses in the north eastern Himalay an region of India. Archives of Agronomy and Soil Science, 64(9), 1254-1267. https://doi.org/10.1080/03650340.2018.1423555

\section{Copyright Disclaimer}

Copyright for this article is retained by the author(s), with first publication rights granted to the journal.

This is an open-access article distributed under the terms and conditions of the Creative Commons Attribution license (http://creativecommons.org/licenses/by/4.0/). 